\title{
PERANCANGAN DIREKTORI RUMAH TAHFIDZ BERBASIS WEB DI KOTA PADANG
}

\author{
Nabila Mukhriza*, Ahmad Fauzi*, \& Rahmi Yunita*
}

*Ilmu Perpustakaan, Universitas Islam Negeri Imam Bonjol, Padang

Email: mukrizanabila@gmail.com, ahmadfauzi@uinib.ac.id, rahmiyunita19@gmail.com

(Submitted: 28-12-2019, Revised: 28-03-2020, Accepted: 02-06-2020)

DOI: 10.24252/kah.v8i1a1

\begin{abstract}
ABSTRAK: Suku Minangkabau memiliki falsafah yang berpedoman kepada syariat Islam. Salah satu falsafah tersebut yaitu "Adat basandi Syara' dan Syara' basandikan Kitabullah" yang artinya adat bersanding dengan syariat, dan syariat berdasarkan al-Qur'an. Kota Padang sebagai Ibu Kota provinsi Sumatra Barat yang ditinggali oleh masyarakat Minangkabau memiliki program untuk menjadikan kota ini sebagai kota penghafal al-Qur'an. Tujuan dari penelitian ini yaitu untuk membuat sistem direktori berbasis web tentang rumah tahfidz di Kota Padang. Metode penelitian dilakukan dengan wawancara dan studi lapangan. Pembuatan sistem sendiri dimulai dari analisis kebutuhan, perancangan, pembuatan sistem, dan uji coba. Sistem direktori rumah tahfidz dibangun dengan menggunakan bahasa pemrograman PHP dan database MySQL. Sistem yang dibangun terdiri dari halaman Content Management System (CMS) untuk administrator dan halaman untuk pengguna umum. Sistem diuji dengan menggunakan perangkat desktop dan mobile dengan variasi peramban internet. Hasil pengujian sistem menunjukkan tingkat availability dapat berjalan baik pada perangkat desktop dan mobile.
\end{abstract}

Kata kunci: Direktori; Rumah Tahfidz; aplikasi web

\section{WEB-BASED DESIGN OF “RUMAH TAHFIDZ” DIRECTORY IN PADANG}

\begin{abstract}
Minangkabau tribe have philosophies based on Islamic law. One of its philosophies is "Adat basandi Syara', Syara' basandikan Kitabullah", that means the culture and Islamic law work together, and Islamic law is based on Alquran. Padang as the main city of West Sumatra occupied by Minangkabau society has a program to make the city as hafidz city (memorizing Quran verses). The data were gathered through interview and study field. The steps to build the system are requirement analysis, designing, coding (building application), and testing. The system was built by PHP programming language and MySQL for database. The system was consisting of Content Management System (CMS) for administrator and pages for public use. The system is tested by using desktop and mobile devices through internet browsers. The result shows the availability of the system worked properly on desktop and mobile devices.
\end{abstract}

Keywords: Directory; tahfidz houses; web application

\section{PENDAHULUAN}

Sumatra Barat merupakan provinsi yang mana mayoritas penduduknya ditinggali oleh Suku Minangkabau. Suku Minangkabau sendiri merupakan suku dengan mayoritas penganut agama Islam. Berdasarkan data hasil sensus penduduk yang dilakukan oleh Badan Pusat Statistik Indonesia pada tahun 2010 tercatat jumlah penduduk Muslim di Sumatra Barat ialah 4.721.924 jiwa dari total keseluruhan 4.846.909 jiwa (BPS, 2010). Suku Minangkabau memiliki falsafah yang berpedoman kepada ajaran Islam, salah satunya yaitu Adat basandi Syara' dan Syara' basandikan Kitabullah. Artinya, adat bersanding dengan syariat, dan syariat berdasarkan 
kitabullah (al-Qur'an). Berdasarkan falsafah tersebut, adat Minangkabau harus bersinergi dengan nilai-nilai yang bersumber dari al-Qur'an.

Kota Padang sebagai Ibu Kota Provinsi Sumatra Barat menjadi pusat kegiatan masyarakat Minangkabau, khususnya kegiatan bernuansa Islam. Hal ini dapat dilihat dari salah satu program Pemerintah Kota Padang yang ingin menjadikan Kota Padang sebagai Kota Penghafal al-Qur'an (Okezone, 2018). Akibat dari program ini, orang tua menjadi semangat untuk menitipkan anaknya ke Rumah Tahfidz. Tidak hanya anak-anak, orang dewasa pun sangat antusias untuk mengikuti program tahfidz yang ditawarkan oleh Rumah Tahfidz yang ada di Kota Padang. Pemilihan Rumah Tahfidz oleh para calon penghafal al-Qur'an didasarkan pada program yang ditawarkan dan juga lokasi Rumah Tahfidz tersebut berada.

Direktori merupakan salah satu dari sekian macam buku sumber atau koleksi rujukan. Direktori juga dikenal sebagai buku rujukan. Direktori merupakan daftar yang disusun secara sistematis mengenai daftar tokoh, organisasi atau lembaga, yang memberikan data informasi berupa nama, alamat, afiliasi, kegiatan, dan sebagainya yang diurut berdasarkan abjad, kelas atau subjek (Sulistyo-Basuki, 2001). Bob dan Smith mendefinisikan direktori adalah daftar orang atau organisasi yang disusun secara sistematis, direktori biasanya dalam urutan abjad atau klasifikasi, memberikan alamat, afiliasi, dan lainnya. Muhammad Azwar Muin menyatakan bahwa direktori merupakan mesin pencarian yang mengelompokkan website dalam hierarki dan direktori berdasarkan subjek atau topik tertentu (Muin, 2014).

Katz membagi direktori ke dalam 6 kelompok (Yusup, 2016), yaitu:

1) Direktori Lokal, biasanya terbatas hanya berupa buku telepon dan direktori kota setempat.

2) Direktori Pemerintah, umumnya diterbitkan oleh pemerintah kota setempat dalam rangka menyebarluaskan informasi tentang lembaga dan data lainnya yang dianggap penting kepada masyarakat luas.

3) Direktori Lembaga, berupa daftar lembaga - lembaga seperti sekolah, yayasan, perguruan tinggi, kantor - kantor pemerintah, dan lembaga serupa.

4) Pelayanan Investasi, erat kaitannya dengan direktori perdagangan dan bisnis yang memberi laporan rinci akan perusahaan, perorangan, umum, maupun gabungan keduanya.

5) Direktori Profesional, secara luas mendaftar organisasi - organisasi profesional seperti ahli hukum, dokter, pustakawan, dan para ilmuwan bidang lainnya.

6) Direktori Perusahaan, berisi segala informasi yang dihasilkan pabrik atau perusahaan, industri, dan perdagangan.

Adapun direktori yang dibuat dalam penelitian ini termasuk ke dalam jenis direktori lembaga. Direktori lembaga yang dimaksud yaitu direktori Rumah Tahfidz yang merupakan pusat pendidikan dan ilmu pengetahuan mengenai ilmu al-Qur'an.

Istilah Rumah Tahfidz merupakan gabungan dari kata rumah dan tahfidz. Rumah diartikan sebagai bangunan maupun tempat tinggal. Sedangkan, tahfidz berasal dari bahasa Arab hafadzo artinya menjaga. Tahfidz sendiri identik dengan kegiatan menghafal (menjaga) al-Qur'an. Rumah Tahfidz ialah rumah ataupun tempat yang dijadikan tempat menjaga hafalan al-Qur'an (Mahardika, 2013). Tahfidz bertindak sebagai penggerak dakwah al-Qur'an di tengah masyarakat dalam bentuk komunitas, masjid, sekolah, perguruan tinggi, maupun instansi. Dengan kata lain, Rumah Tahfidz merupakan sebuah lembaga non pesantren dengan aktivitas penghafalan al-Qur'an, pengamalan, serta membudayakan nilai-nilai yang terkandung di dalam al-Quran ke dalam kehidupan sehari-hari berbasiskan hunian, lingkungan, dan komunitas (Yayasan Darul Quran Nusantara, 2007).

Pembuatan direktori Rumah Tahfidz di Kota Padang sebelumnya telah dilakukan oleh Afriami \& Rahma (2017). Hasil dari penelitian Afiami dan Rahma menghasilkan direktori rumah tahfidz dalam bentuk buku berisikan informasi 38 rumah Tahfidz di Kota Padang. Penelitian sejenis juga dilakukan oleh Yova \& Marlini (2017) terkait dengan pendirektorian tempat wisata di Kota Bukittinggi. Hasil observasi lapangan penelitian ini menghasilkan direktori berbentuk 
buku yang menginformasikan 14 tempat wisata di Kota Bukit Tinggi dan 12 tempat wisata di Kabupaten Agama.

Penelitian terkait direktori berbasis web dilakukan oleh Pratiwi dan Ardoni (2018). Penelitian tersebut membuat direktori rental mobil di Kota Padang berbasis web. Pembuatan direktori rental mobil menggunakan bahasa pemrograman PHP dan database MySQL. Penelitian direktori berbasis web juga dilakukan oleh Prastiwi (2014), yaitu membuat direktori judul skripsi. Tujuan dari penelitian tersebut yaitu untuk membantu dosen atau mahasiswa mengecek judul skripsi yang sudah dibuat agar tidak ada judul skripsi yang sama. Penelitian tersebut menggunakan bahasa pemprograman PHP dan database MySQL.

Berdasarkan wawancara yang dilakukan terhadap pegawai Kantor Wilayah (Kanwil) Kementerian Agama (Kemenag) Sumatra Barat, pada tahun 2016 tercatat sebanyak 60 Rumah Tahfidz yang telah terdata dalam bentuk daftar tabel di Kanwil Kemenag Sumatra Barat. Namun, masih ada Rumah Tahfidz yang belum terdata alamat beserta informasi lainnya. Selain itu data tersebut merupakan data tahun 2016 dan belum diperbaharui. Berdasarkan permasalahan tersebut, tujuan dari penelitian ini yaitu membuat Sistem Direktori Berbasis Web tentang Rumah Tahfidz di Kota Padang. Sistem ini berisi tentang informasi yang memudahkan pencari Rumah Tahfidz untuk memilih Rumah Tahfidz yang diinginkan.

\section{METODOLOGI PENELITIAN}

Penelitian ini menggunakan metode deskriptif dengan mengambil data melalui wawancara dan studi lapangan. Workflow penelitian ini dapat dilihat pada Gambar 1. Tahap awal penelitian yaitu melakukan analisis kebutuhan terhadap stakeholders Rumah Tahfidz di Kota Padang. Stakeholders yang diwawancarai meliputi seorang pegawai Kanwil Kementerian Agama Sumatra Barat, 10 orang mahasiswa UIN Imam Bonjol Padang, dan 10 orang tua di Kota Padang yang memiliki anak bersekolah SD. Hasil analisis kebutuhan digunakan sebagai input untuk melakukan pengambilan data.

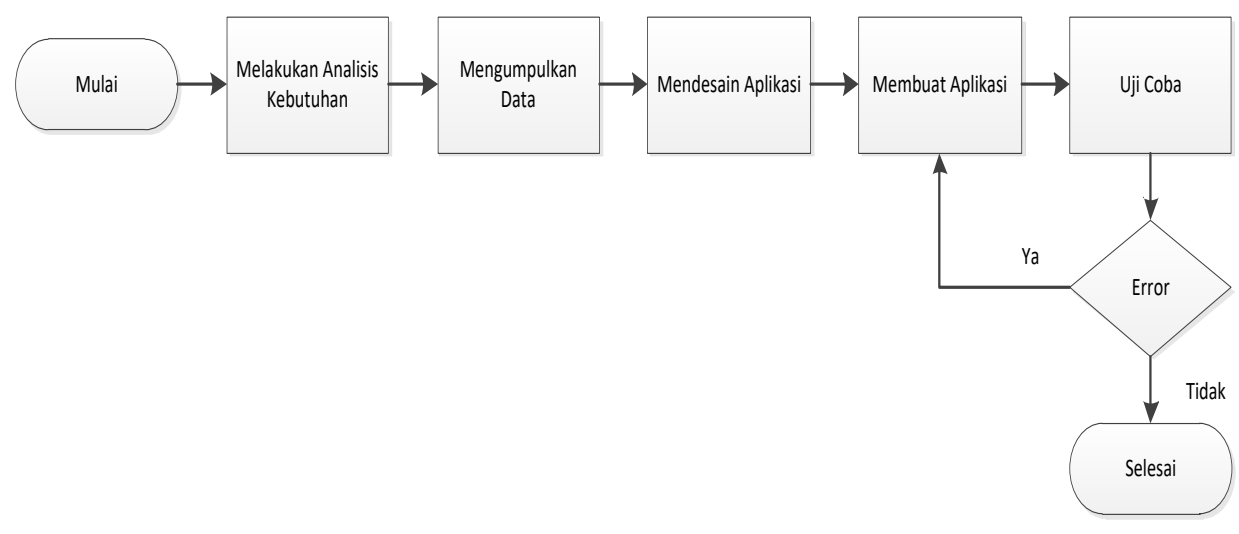

Gambar 1. Workflow penelitian

Tahapan selanjutnya yaitu mengumpulkan data terkait informasi yang relevan untuk dimasukkan ke dalam sistem direktori berdasarkan hasil dari analisis kebutuhan. Proses mengumpulkan data dilakukan dengan studi lapangan dan wawancara. Survei lapangan dilakukan untuk mengambil foto Rumah Tahfidz dan juga koordinat lokasi rumah tahfidz yang nantinya terintegrasi dengan Google Maps. Cara penentuan koordinat lokasi dengan menyetel GPS handphone ketika berada di lokasi Rumah Tahfidz yang dituju kemudian disimpan ke dalam Google Maps. Selain pengambilan foto dan koordinat lokasi, pengambilan data juga dilakukan dengan mewawancarai pengelola Rumah Tahfidz untuk mendapatkan informasi nama, nomor kontak, dan program Rumah Tahfidz.

Desain aplikasi dibagi menjadi desain database dan desain aplikasi. Desain database terbatas hanya pada tingkat conceptual design yang mana menerjemahkan dari data yang 
diperoleh pada tahapan analisis kebutuhan dan pengumpulan data. Diagram usecase sistem direktori Rumah Tahfidz dapat dilihat pada

Gambar 2, desain aplikasi sendiri terdiri dari desain untuk administrator yang memiliki tugas memasukkan informasi terkait Rumah Tahfidz ke dalam Content Management System (CMS) dan desain untuk pengguna umum yang pengguna umum dapat melihat informasi yang telah dimasukkan oleh administrator sebelumnya. Agar dapat memasukkan informasi ke dalam CMS, administrator perlu login terlebih dahulu.

Pembuatan sistem direktori Rumah Tahfidz dibangun dengan menggunakan bahasa pemrograman PHP dengan framework Laravel 5.5 dan database MySQL. Penggunaan Laravel sendiri didasarkan atas popularitasnya pada tahun 2019 yang menempati urutan teratas dibandingkan framework PHP lainnya (

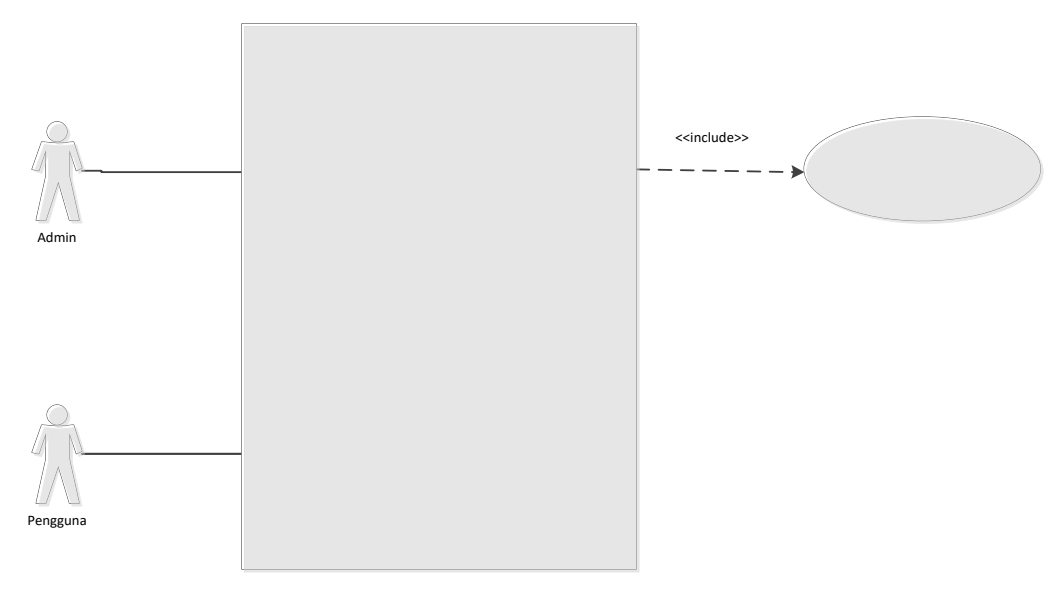

Gambar 2. Diagram usecase sistem direktori Rumah Tahfidz

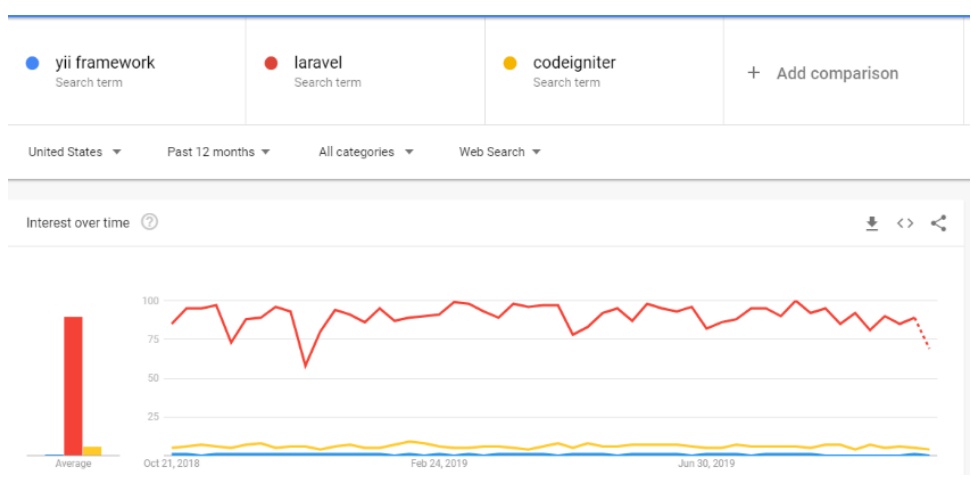

Gambar 3. Perbandingan popularitas framework PHP tahun 2019 berdasarkan Google Trends (Diakses 18 Oktober 2019)

Uji coba aplikasi dilakukan untuk mengetahui tingkat availability (ketersediaan) dari sistem dengan mengujinya di perangkat desktop maupun mobile. Selain dengan menggunakan desktop dan mobile, pengujian sistem juga dilakukan dengan menggunakan perambah internet yang berbeda-beda. Apabila dalam proses uji coba ditemukan error (kesalahan), maka dilakukan perbaikan pada tahapan pembuatan sistem. Namun jika tidak ditemukan kesalahan, maka sistem direktori selesai dibuat dan siap untuk digunakan. 


\section{HASIL DAN PEMBAHASAN}

Rumah Tahfidz yang dimasukkan ke dalam sistem Rumah Tahfidz ini berjumkah 48 rumah tahfidz (Tabel 1). Informasi tentang Rumah Tahfidz tersebut dimasukkan ke dalam sistem oleh administrator melalui CMS yang meliputi nama rumah tahfidz, nama pimpinan, alamat, kontak, program yang ditawarkan oleh Rumah Tahfidz, serta koordinat lokasi Rumah Tahfidz (

Gambar 4). Untuk koordinat lokasi, admin memasukkan koordinat yang telah di dapatkan dari studi lapangan dengan menyesuikan GPS lokasi Rumah tahfidz dengan Google Maps.

Tabel 1. Daftar Rumah Tahfidz di Kota Padang

\begin{tabular}{|c|c|c|}
\hline Nama Rumah Tahfidz & Alamat & Program \\
\hline Ahlul Quran & $\begin{array}{l}\text { Kubu Dalam Parak Karakah, } \\
\text { Kec. Padang Timur, Padang }\end{array}$ & Tahsin, Tahfidz \\
\hline Ar Rasyid & $\begin{array}{l}\text { Jl. Rimbo Data No.49, RT } 02 \\
\text { RW 02, Kel. Bandar Buat, Kec. } \\
\text { Lubuk Kilangan, Padang } \\
\text { (Belakang SMP LUKI) }\end{array}$ & $\begin{array}{l}\text { Tahfidz, Seni Irama dan Muratta } \\
\text { Pidato/MSQ, Hafalan Shalat }\end{array}$ \\
\hline Dar El Huffazh & $\begin{array}{l}\text { Jl. Tanjung Berok 17, Kurao } \\
\text { Pagang, Kec. Nanggalo, Padang }\end{array}$ & Tilawah, Tahsin, Tahfidz \\
\hline Darul Quran & $\begin{array}{l}\text { Jl. Sumatra 5, Ulak Karang } \\
\text { Utara, Kec. Padang Utara, } \\
\text { Padang }\end{array}$ & $\begin{array}{l}\text { Mondok (Hafidz } 30 \text { Jus } \\
\text { tahun+belajar bahasa Arab), Tahsin } \\
\text { Tahfidz - Regular/Non Mondol } \\
\text { (Tahsin dan Tahfidz) }\end{array}$ \\
\hline Quran & Jl. Bunga Tanjung, Kel. Batipuh & Tahsin, Tahfidz \\
\hline Balad & $\begin{array}{l}\text { Panjang, Kec. Koto Tangah, } \\
\text { Padang }\end{array}$ & \\
\hline Masjid Al Hidayah & $\begin{array}{l}\text { Jl. Semarang, Kel. Surau } \\
\text { Gadang, Kec. Nanggalo, Kota } \\
\text { Padang }\end{array}$ & Hifzhil, Tartil, Tahfidz \\
\hline Masjid Al Hijrah & $\begin{array}{l}\text { Kel. Tabing Banda Gadang, } \\
\text { Nanggalo, Padang }\end{array}$ & Tilawah, Tartil, Tahfidz \\
\hline Masjid Al Mukhlisin & $\begin{array}{l}\text { Gg. Loko, Pampangan Nan XX, } \\
\text { Kec. Lubuk Begalung, Kota } \\
\text { Padang }\end{array}$ & Tahfidz \\
\hline Masjid Al-Hasanah & $\begin{array}{l}\text { Jl. Tanah Sirah Piai Nan XX, } \\
\text { Kecamatan Lubuk Begalung, } \\
\text { Padang }\end{array}$ & Tahfidz \\
\hline Masjid An-Nur Syukur & $\begin{array}{l}\text { Jl. Raya Indarung No.25, Kel. } \\
\text { Indarung, Kec. Lubuk } \\
\text { Kilangan, Padang }\end{array}$ & Tilawah, Tartil, Tahfidz \\
\hline Masjid Baitun Nikmah & $\begin{array}{l}\text { Kelurahan Parak Laweh Nan } \\
\text { XX, Kecamatan Lubuk } \\
\text { Begalung, Padang }\end{array}$ & Tartil, Tahfidz \\
\hline Masjid Bitul Makmur & $\begin{array}{l}\text { Gurun Laweh, Nanggalo, } \\
\text { Padang }\end{array}$ & Tilawah, Tartil, Tahfidz \\
\hline Masjid Darul Muttaqin & $\begin{array}{l}\text { Dadok Tunggul Hitam, Koto } \\
\text { Tangah, Padang }\end{array}$ & Tahfidz \\
\hline Masjid Jami' & $\begin{array}{l}\text { Lubuk Sarik, Kel. Padang Besi, } \\
\text { Kec.Lubuk Kilangan, Padang }\end{array}$ & Tilawah, Tartil, Tahfidz, MHQ, MSQ \\
\hline Masjid Jihad & $\begin{array}{l}\text { Kampung Olo, Nanggalo, } \\
\text { Padang }\end{array}$ & Tilawah, Tartil, Tahfidz \\
\hline
\end{tabular}




\begin{tabular}{|c|c|c|}
\hline Nama Rumah Tahfidz & Alamat & Program \\
\hline Masjid Nurul Hidayah & $\begin{array}{l}\text { Jl. Bukit Ngalau, Kel. Indarung, } \\
\text { Kec. Lubuk Kilangan, Padang }\end{array}$ & $\begin{array}{l}\text { Tilawah, Tartil, } \\
\text { Khutbah, MSQ }\end{array}$ \\
\hline Masjid Nurul Wujud & $\begin{array}{l}\text { Beringin, Kecamatan Lubuk } \\
\text { Kilangan, Padang }\end{array}$ & Tilawah, Tartil, Tahfidz, MHQ, MSQ \\
\hline Masjid Nurus Sakinah & $\begin{array}{l}\text { Jl. Palangka Raya No.2, Ulak } \\
\text { Karang Sel., Kec. Padang Utara, } \\
\text { Padang }\end{array}$ & TPQ sekaligus Tahfidz \\
\hline Masjid & Gg. Makmur, Andalas, Kel. & Tilawah, Tahfidz \\
\hline $\begin{array}{l}\text { Biturrahmah Andalas } \\
\text { Makmur }\end{array}$ & $\begin{array}{l}\text { Kubu Dalam Parak Karakah, } \\
\text { Kec. Padang Timur, Kota } \\
\text { Padang }\end{array}$ & \\
\hline Mushalla Al Ikhlas & $\begin{array}{l}\text { Jl. Kp. Jua RT.03 RW. 03, Kel. } \\
\text { Tarantang, Kec. Lubuk } \\
\text { Kilangan }\end{array}$ & Tilawah, Tartil, MHQ, MSQ \\
\hline Mushalla Al-Amin & $\begin{array}{l}\text { Kel. Bukit Gado-Gado, } \\
\text { Kecamatan Padang Selatan }\end{array}$ & Tahsin dan Tahfidz \\
\hline Mushalla Nurul Yaqin & $\begin{array}{l}\text { Jln. Koto Lalang, Kel. Koto } \\
\text { Lalang, Kec. Lubuk Kilangan, } \\
\text { Padang }\end{array}$ & Tilawah, Tartil \\
\hline Nurul Quran & $\begin{array}{l}\text { Jl. Sawah Liat No.36, Kel, Kp. } \\
\text { Olo, Kec. Nanggalo, Padang }\end{array}$ & $\begin{array}{l}\text { Tahsin, Tahfidz, Pealajaran Do'a dan } \\
\text { Hadits, Praktek Sholat }\end{array}$ \\
\hline $\begin{array}{ll}\text { Pengajian } & \text { Siti Hawa } \\
\text { (KUA) } & \text { Kecamatan }\end{array}$ & $\begin{array}{l}\text { Jl. S. Parman Belakang Taman } \\
\text { Makam Pahlawan, Kel. Lolong }\end{array}$ & $\begin{array}{l}\text { Tilawah dan Tahsin (Khusus untuk } \\
\text { para dewasa yang mau }\end{array}$ \\
\hline Padang Utara & $\begin{array}{l}\text { Belanti, Kec. Padang Utara, } \\
\text { Padang }\end{array}$ & $\begin{array}{l}\text { memepelajari dan membenarkan } \\
\text { baca alquran terutama warga } \\
\text { Kecamatan Padang Utara) }\end{array}$ \\
\hline $\begin{array}{l}\text { Pondok Al Qur'an Ahlus } \\
\text { Sunnah Wal Jamaah }\end{array}$ & $\begin{array}{l}\text { Jl. Piai Tangah RT } 02 \text { RW 01, } \\
\text { Kec. Pauh }\end{array}$ & Tahsin, Tahfidz \\
\hline $\begin{array}{l}\text { Pondok Alquran Madjid } \\
\text { Arafah }\end{array}$ & $\begin{array}{l}\text { Kampung Baru Berok, Kel. } \\
\text { Kurao Pagang, Kec. Nanggalo }\end{array}$ & Tilawah, Tartil, Tahfidz \\
\hline 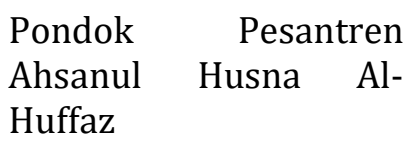 & $\begin{array}{l}\text { Kayu Aro Kel. Bungus Barat, } \\
\text { Kec. Bungus, Padang }\end{array}$ & $\begin{array}{l}\text { Tahsin, Metode Piala Dunia Al } \\
\text { Hafidz }\end{array}$ \\
\hline $\begin{array}{ll}\text { Pondok Qur'an } & \text { (KUA) } \\
\text { Kecamatan } & \text { Lubuk } \\
\text { Kilangan } & \end{array}$ & $\begin{array}{l}\text { Jl. Raya Gadut, Kel. Bandar } \\
\text { Buat, Kec. Lubuk Kilangan, } \\
\text { Padang }\end{array}$ & $\begin{array}{l}\text { Tilawah, Tartil, Tahfidz, Khutbah, } \\
\text { MSQ }\end{array}$ \\
\hline RA Sabitul Qalbi & $\begin{array}{l}\text { Komplek Marta Indah, Gg. } \\
\text { Rambutan No.3, Kel. Aia } \\
\text { Pacah, Kec. Kuranji, Padang }\end{array}$ & $\begin{array}{l}\text { Tahsin, Tahfidz (untuk anak-remaja } \\
\text { usia sekolah) -Majlis Ta'lim Rumah } \\
\text { Suluah untuk Wanita }\end{array}$ \\
\hline Rumah Qur'an Al Husna & $\begin{array}{l}\text { Perum. Villa Berlian Asri Blok } \\
\text { B9 Air Dingin, Kel. Balai } \\
\text { Gadang, Kec. Koto Tangah, } \\
\text { Kota Padang }\end{array}$ & $\begin{array}{l}\text { Menulis, Membaca, dan Menghafal } \\
\text { Alquran }\end{array}$ \\
\hline Rumah Quran Al Uswah & $\begin{array}{l}\text { Jl. Lolo Gunung Sarik RT } 02 \\
\text { RW 01, Kel. Gunung Sarik, Kec. } \\
\text { Kuranji, Padang }\end{array}$ & Tahsin, Tahfidz \\
\hline Rumah Quran Rabbani & $\begin{array}{l}\text { Jl. Arai Pinang, Batung Taba } \\
\text { Nan XX, Kec. Lubuk Begalung, } \\
\text { Padang }\end{array}$ & $\begin{array}{l}\text { Tahsin, Tahfidz, Kajian Subuh dan } \\
\text { Magrib }\end{array}$ \\
\hline
\end{tabular}




\begin{tabular}{|c|c|c|}
\hline Nama Rumah Tahfidz & Alamat & Program \\
\hline $\begin{array}{l}\text { Rumah Quran Serambi } \\
\text { Minang }\end{array}$ & $\begin{array}{l}\text { Jl. Durian Taruang No. } 55 \text { Ps. } \\
\text { Ambacang, Kec. Kuranji, } \\
\text { Padang }\end{array}$ & Tahsin, Tahfidz \\
\hline $\begin{array}{lcl}\text { Rumah } & \text { Tahfidz } & \mathrm{Al} \\
\text { Hannag } & & \end{array}$ & $\begin{array}{l}\text { Perumahan Griya Anak Air } \\
\text { Permai, Kel. Batipuh Panjang, } \\
\text { Kec. Koto Tangah, Padang }\end{array}$ & Tahsin, Tahfidz \\
\hline Rumah Tahfidz Al Ihsan & $\begin{array}{l}\text { Jl. Raya Banda Buek RT } 1 \text { RW } \\
\text { 4, Kel. Bandar Buat, Kec. } \\
\text { Lubuk Kilangan, Padang }\end{array}$ & Tahsin dan Tahfidz \\
\hline $\begin{array}{l}\text { Rumah } \\
\text { Ansharullah }\end{array}$ & $\begin{array}{l}\text { Jl. Rawang Timur } 7 \text { No. 10, Kel. } \\
\text { Rawang, Kec. Padang Selatan, } \\
\text { Kota Padang }\end{array}$ & Tahsin dan Tahfidz \\
\hline $\begin{array}{l}\text { Rumah } \\
\text { Rabbani }\end{array}$ & $\begin{array}{l}\text { Jl. Kampung Dalam RT } 01 \text { RW } \\
\text { 01, Kec. Pauh, Padang }\end{array}$ & Tahsin, Tahfidz \\
\hline $\begin{array}{lll}\text { Rumah } & \text { Tahfidz } & \text { Ar } \\
\text { Rahmah } & & \end{array}$ & $\begin{array}{l}\text { Jl. Sawah Liat No.32, Kel, Kp. } \\
\text { Olo, Kec. Nanggalo, Kota } \\
\text { Padang }\end{array}$ & Tahsin, Tahfidz \\
\hline $\begin{array}{lll}\text { Rumah } & \text { Tahfidz } & \text { Ar- } \\
\text { Rahman } & & \end{array}$ & $\begin{array}{l}\text { Jl. Jati IV No.9, Jati Baru, Kec. } \\
\text { Padang Timur, Kota Padang }\end{array}$ & Hifzhil, Tahfidz, Pidato \\
\hline $\begin{array}{l}\text { Rumah Tahfidz Baitul } \\
\text { Hadi Mandiri }\end{array}$ & $\begin{array}{l}\text { Jl. Aur Duri Indah X, Kel. Parak } \\
\text { Gadang Timur, Kec. Padang } \\
\text { Timur, Kota Padang }\end{array}$ & $\begin{array}{l}\text { Bimbingan Baca Quran, Tahsin, dan } \\
\text { Tahfidz }\end{array}$ \\
\hline $\begin{array}{l}\text { Rumah Tahfidz } \\
\text { Bustanul Quran }\end{array}$ & $\begin{array}{l}\text { Jl. Delima I Blok A No, } 208 \\
\text { Perumnas } \\
\text { Kuranji }\end{array}$ & Talaqi, Tahsin, Tahfidz \\
\hline $\begin{array}{l}\text { Rumah Tahfidz Griya } \\
\text { Anak Sholih }\end{array}$ & $\begin{array}{l}\text { Kompek Atap Genteng Blok F1 } \\
\text { no.13, Indarung, Kec. Lubuk } \\
\text { Kilangan, Padang }\end{array}$ & Tahsin dan Tahfidz \\
\hline $\begin{array}{l}\text { Rumah Tahfidz Kauny } \\
\text { Qur'anic School Ummu } \\
\text { Ranaa I }\end{array}$ & $\begin{array}{l}\text { Villaku Indah } 3 \text { RT } 3 \text { RW } 3 \text { Kel. } \\
\text { Sungai Sapih, Kec. Kuranji, } \\
\text { Kota Padang }\end{array}$ & $\begin{array}{l}\text { Tahsin, Tahfidz, Tilawah, Metode } \\
\text { Kauny }\end{array}$ \\
\hline $\begin{array}{l}\text { Rumah Tahfidz Kauny } \\
\text { Qur'anic School Ummu } \\
\text { Ranaa II }\end{array}$ & $\begin{array}{l}\text { Villa Anggrek, Blok 0.11, RT } \\
04 \text { RW 14, Kel. Balai Gadang, } \\
\text { Kec. Koto Tangah, Padang }\end{array}$ & $\begin{array}{l}\text { Tahsin, Tahfidz, Tilawah, Metode } \\
\text { Kauny }\end{array}$ \\
\hline $\begin{array}{l}\text { Rumah Tahfidz Kauny } \\
\text { Qur'anic School Ummu } \\
\text { Ranaa III }\end{array}$ & $\begin{array}{l}\text { Perumahan Taharudin No.11, } \\
\text { Kel. Batipuh Panjang, Kec. } \\
\text { Koto Tangah, Padang }\end{array}$ & $\begin{array}{l}\text { Tahsin, Tahfidz, Tilawah, Metode } \\
\text { Kauny }\end{array}$ \\
\hline $\begin{array}{l}\text { Rumah Tahfidz Kauny } \\
\text { Qur'anic School Ummu } \\
\text { Ranaa IV }\end{array}$ & $\begin{array}{l}\text { Jl. Marapalam Indah } 9 \text { No.7A } \\
\text { RT 02 RW 08, Kel. Kubu } \\
\text { Marapalam, Kec. Padang } \\
\text { Timur, Padang }\end{array}$ & $\begin{array}{l}\text { Tahsin, Tahfidz, Tilawah, Metode } \\
\text { Kauny }\end{array}$ \\
\hline $\begin{array}{l}\text { Rumah Tahfidz MMQ } \\
\text { Jet Tempur }\end{array}$ & $\begin{array}{l}\text { Jl. Lolo Gunung Sarik, Komplek } \\
\text { Melati } 3 \text { B.5, Kel. Gunung Sarik } \\
\text { Kecamatan Kuranji }\end{array}$ & Tahsin, Tahfidz, Kitab Kuning \\
\hline $\begin{array}{l}\text { Rumah Tahfidz Pejuang } \\
\text { Subuh II }\end{array}$ & $\begin{array}{l}\text { Jl. Selasih 1-3, Parupuk Tabing, } \\
\text { Kec. Koto Tangah, Padang }\end{array}$ & Tahsin dan Tahfidz \\
\hline
\end{tabular}




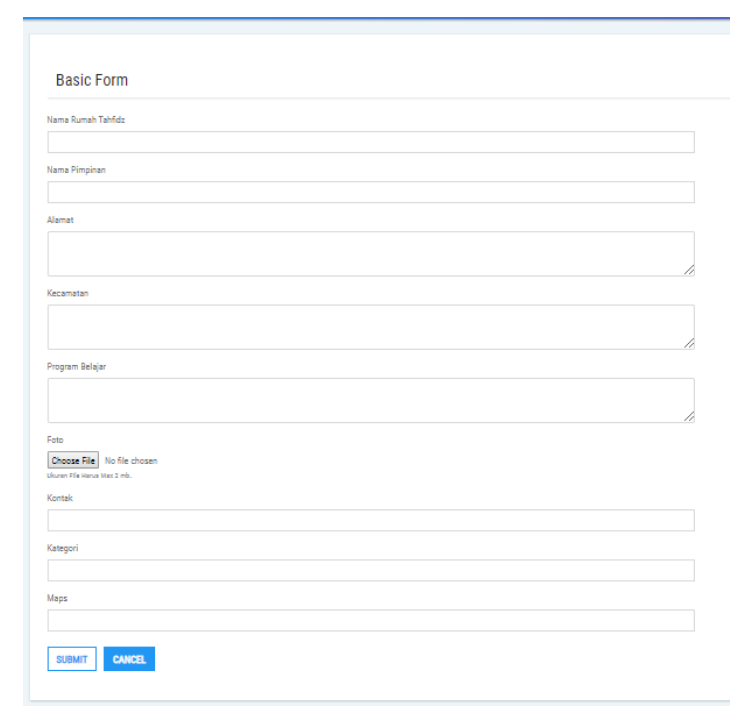

Gambar 4. Halaman Content Management System (CMS)

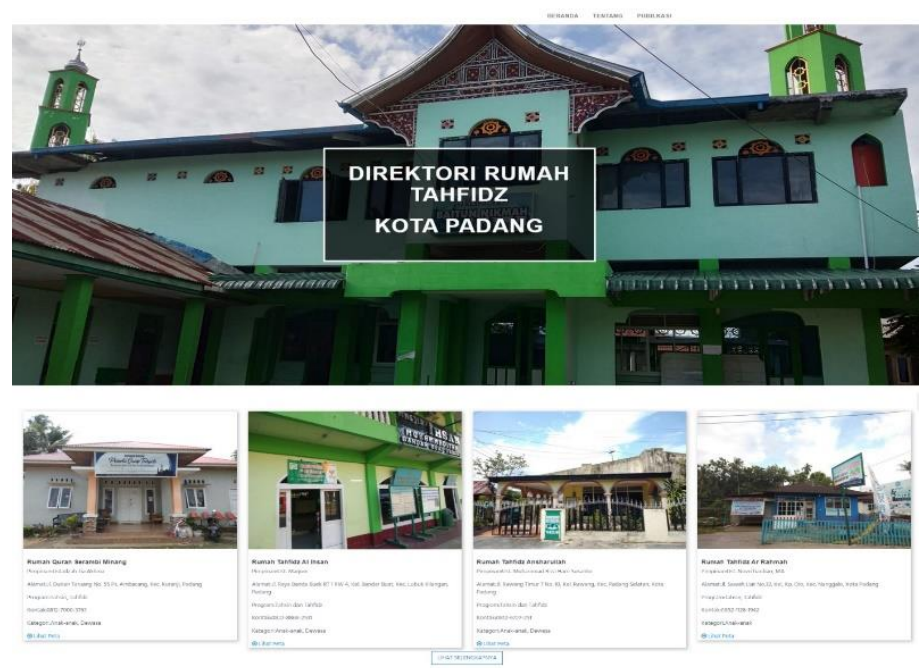

Gambar 5. Halaman pengguna umum

Gambar 5. menunjukkan beranda depan Rumah Tahfidz. Daftar direktori Rumah Tahfidz diurutkan berdasarkan huruf abjad. Untuk melihat peta lokasi Rumah Tahfidz, pengguna umum dapat melihatnya dengan memilih salah satu Rumah Tahfidz. Peta dari lokasi Rumah Tahfidz ditunjukkan oleh Gambar 6.

Pengujian sistem direktori Rumah Tahfidz di Kota Padang dilakukan dengan menggunakan perangkat desktop dan mobile untuk mengetahui availability dari sistem. Selain itu, pengujian sistem juga dilakukan dengan memvariasikan peramban internet. Hasil uji coba availability sistem dapat dilihat pada Tabel 2. 


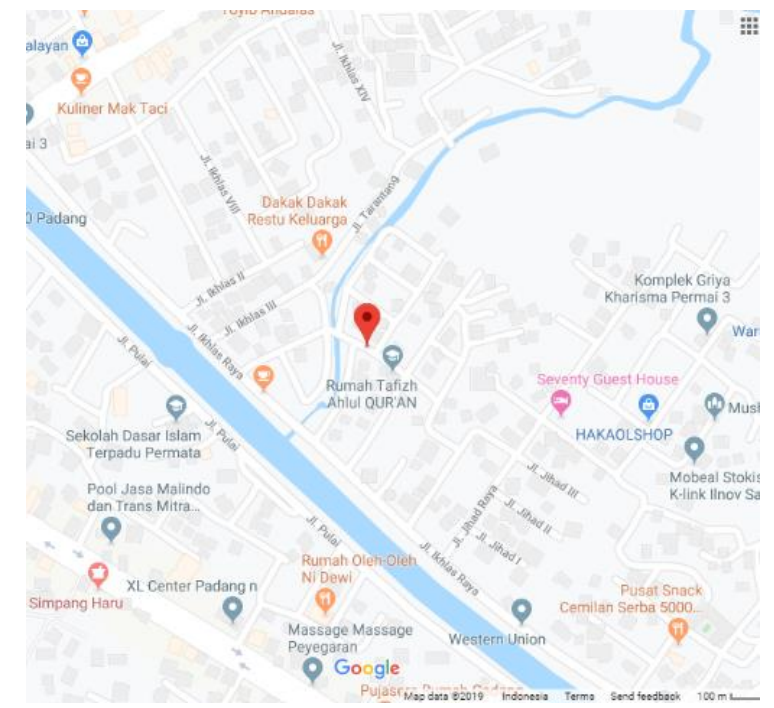

Gambar 6. Peta Rumah Tahfidz Ahlul Quran

Tabel 2 . Hasil Pengujian Sistem Direktori Rumah Tahfidz

\begin{tabular}{llll}
\hline $\begin{array}{l}\text { Jenis } \\
\text { Perangkat }\end{array}$ & \multicolumn{1}{c}{ Operating System } & Web browser & $\begin{array}{c}\text { Hasil } \\
\text { Pengujian }\end{array}$ \\
\hline Desktop & $\begin{array}{l}\text { Window 10, Core i3 } \\
\text { RAM 4 GB }\end{array}$ & Chrome & Berjalan baik \\
& $\begin{array}{l}\text { Window 10, Core i3 } \\
\text { Desktop }\end{array}$ & $\begin{array}{l}\text { Microsoft } \\
\text { RAM 4 GB }\end{array}$ & Berjalan baik \\
& Edge & Mozilla & Berjalan baik \\
Desktop & Ubuntu 14.04, RAM 4GB & Firefox & Berjalan baik \\
Desktop & Ubuntu 14.04, RAM 4GB Chrome & Chrom \\
Mobile & Android 6.0, RAM 2 GB & Opera Mini & Berjalan baik \\
Mobile & Android 6.0, RAM 2 GB & UC Browser & Berjalan baik \\
Mobile & Android 7.0, RAM 2 GB & Chrome & Berjalan baik \\
\hline
\end{tabular}

\section{KESIMPULAN}

Pembuatan sistem direktori Rumah Tahfidz berbasis web menjadi salah satu alternatif yang memudahkan masyarakat untuk mencari informasi terkait Rumah Tahfidz yang diinginkan. Dari hasil pengujian availability sistem direktori Rumah Tahfidz, sistem ini berjalan baik untuk semua perangkat baik desktop dan mobile. Selain itu, karena sistem ini berbasis web, pengujian juga dilakukan dengan memvariasikan peramban internet yang digunakan.

Pembuatan sistem direktori berbasis web ini diharapkan memunculkan direktori-direktori lainnya berbasis web sehingga dapat diakses oleh pengguna umum yang ingin mencari informasi. Penelitian selanjutnya diharapkan penyediaan webservices direktori Rumah Tahfidz. Sehingga dengan adanya webservices, direktori dapat dikembangkan ke berbagai platform termasuk aplikasi mobile (Android dan IOS).

\section{DAFTAR PUSTAKA}

Afriami, Z., \& Rahma, E. (2017). Pembuatan Direktori Rumah Tahfidz Quran se-Kota Padang. Jurnal Ilmu Informasi Perpustakaan dan Kearsipan, 6, 1, 86-94. 
Sulistyo-Basuki. (2001). Pengantar Imu Perpustakaan. Jakarta: Gramedia Pustaka.

BPS. (2010). Diakses 18 Oktober , 2019, dari Badan Pusat Statistik: https://sp2010.bps.go.id/index.php/site?id=13\&wilayah=Sumatra\%20Barat.

Okezone. (2018). Diakses 18 Oktober, 2019, dari Okezone:

https://news.okezone.com/read/2018/01/20/340/1847781/mewujudkan-padang-jadi-kotapenghafal-alquran

Mahardika, E. B. (2013). Peran Rumah Tahfidz Zulfa Qurrata'ayun dalam Pemberdayaan Masyarakat di Desa Purbayan Kota Gede Yogyakarta. Skripsi. UIN Sunan Kalijaga Yogyakarta.

Muin, M. A. (2014). Information Literacy Skills Strategi Penelusuran Informasi. Makasar: Alauddin University Press.

Pratiwi, A, Ardoni. (2018). Direktori Rental Mobil Di Kota Padang Berbasis Website. Jurnal Ilmu Informasi Perpustakaan dan Kearsipan, 6, 2, 46-55.

Prastiwi, J. E. N. (2014). Sistem Informasi Direktori Judul Skripsi Berbasis Web Dengan Menggunakan Php Dan Mysql. Skripsi thesis, Universitas Muhammadiyah Ponorogo.

Yayasan Darul Quran Nusantara. (2007). Profil Lembaga PPA Darul Quran. Jakarta: Lembaga Yayasan PPA Darul Quran.

Yova, W. E., \& Marlini. (2017). Pembuatan Direktori Wisata Di Kota Bukittinggi Dan Kabupaten Agam. Jurnal Ilmu Informasi Perpustakaan dan Kearsipan, 6, 1, 67-77.

Yusup, P. M. (2016). Ilmu Informasi, Komunikasi, dan Kepustakaan. Jakarta: Bumi Aksara. 